\section{PROTECTIVE EFFECTS OF VIRGIN COCONUT OIL AND TOCOTRIENOL-RICH FRACTION ON BONE BIOMECHANICS}

\author{
Mohd Maaruf Abdul Malika*, Dina Fariha Che Ab Ghania, A'isyah \\ Nabila Uzaimia, Ahmad Nazrun Shuidb,c
}

aFaculty of Dentistry, Universiti Teknologi MARA, Sungai Buloh Campus, Jalan Hospital, 47000 Sungai Buloh, Selangor Darul Ehsan, Malaysia

bFaculty of Medicine, Universiti Kebangsaan Malaysia Medical Centre, Jalan Yaacob Latif, 56000 Cheras, Kuala Lumpur, Malaysia Faculty of Medicine, Universiti Teknologi MARA, Sungai Buloh 'Campus, Jalan Hospital, 47000 Sungai Buloh, Selangor Darul Ehsan, Malaysia
Article history

Received

9 August 2019

Received in revised form

12 April 2020

Accepted

30 April 2020

Published online

22 June 2020

\section{*Corresponding author} maaruf@uitm.edu.my

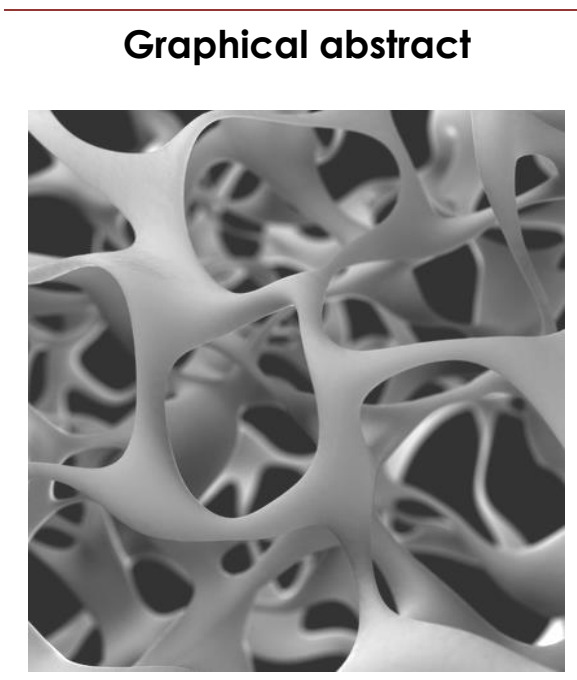

\begin{abstract}
Osteoporosis is a metabolic disease characterized by low bone mineral density. Both virgin coconut oil (VCO) and tocotrienol-rich fraction (TRF) are known to have higher antioxidant activity. The study aimed to determine the effect of combined therapy of VCO and TRF on bone biomechanical strength parameters of the ovariectomised rat model fed with high fat diet and heated palm oil. Thirty-six female Sprague-Dawley rats were divided into; Sham-operated (SHAM), ovariectomised control (OVX) ovariectomised and given Premarin $64.5 \mu \mathrm{g} / \mathrm{kg}(\mathrm{OVX}+\mathrm{P})$, ovariectomised and given $V C O 1.43 \mathrm{ml} / \mathrm{kg}(\mathrm{OVX}+\mathrm{V})$, ovariectomised and given TRF $30 \mathrm{mg} / \mathrm{kg}(\mathrm{OVX}+\mathrm{T})$ and ovariectomised and given combined therapy of VCO and TRF (OVX+VT). Following 24 weeks, the rats were sacrificed and the right femora were analyzed for three-point bending test using Shimadzu machine (AG-X 500 N). The parameters were divided into two classes: extrinsic (load, displacement and stiffness) and intrinsic (stress, strain and Young modulus). The statistical tests used were analysis of variance (ANOVA), followed by Tukey's HSD test. The Young modulus value of OVX+VT group was significantly higher than $O V X+V$ and $O V X+T$ groups $(p<0.05)$. Combined therapy of VCO and TRF have offered better bone protective effects than single dose of VCO or TRF in preventing bone loss of osteoporotic rat model.
\end{abstract}

Keywords: Osteoporosis, virgin coconut oil, tocotrienol-rich fraction, biomechanical strength, three-point bending

\begin{abstract}
Abstrak
Osteoporosis adalah penyakit metabolik yang bercirikan kepada kepadatan mineral tulang yang rendah. Kedua-dua minyak kelapa dara (VCO) dan pecahan kaya tocotrienol (TRF) diketahui mempunyai aktiviti antioksidan yang sangat tinggi. Tujuan kajian ini adalah menentukan kesan terapi kombinasi VCO dan TRF terhadap parameter kekuatan biomekanikal tulang pada model osteoporosis tikus terovariektomi yang diberikan diet tinggi lemak dan minyak sawit yang dipanaskan. Sebanyak tiga puluh enam tikus betina Sprague-Dawley dibahagikan kepada; kawalan Sham (SHAM), kawalan ovariektomi (OVX), terovariektomi dan diberikan Premarin $64.5 \mu \mathrm{g} / \mathrm{kg}(\mathrm{OVX}+\mathrm{P})$, terovariektomi dn diberikan $\mathrm{VCO} 1.43 \mathrm{ml} / \mathrm{kg}(\mathrm{OVX}+\mathrm{V})$, terovariektomi dan diberikan TRF $30 \mathrm{mg} / \mathrm{kg}(\mathrm{OVX}+\mathrm{T})$ dan terovariektomi dan diberikan terapi kombinasi VCO dan TRF (OVX+VT). Selepas 24 minggu, semua tikus telah dibunuh dan tulang femur kanan telah dianalisis bagi ujian pelenturan tiga titik menggunakan mesin Shimadzu (AG-X 500 N). Parameter-parameter telah
\end{abstract}


dibahagikan kepada dua kategori: ekstrinsik (beban, anjakan dan kekakuan) dan intrinsik (tegangan, regangan dan Modulus kekenyalan). Ujian statistikal yang digunakan adalah analisis varians (ANOVA), diikuti dengan ujian Tukey's HSD. Nilai Modulus kekenyalan bagi kumpulan OVX+VT adalah lebih tinggi secara signifikan berbanding kumpulan $\mathrm{OVX}+\mathrm{V}$ dan $\mathrm{OVX}+\mathrm{T}(\mathrm{p}<0.05)$. Terapi kombinasi antara $\mathrm{VCO}$ dan TRF berpotensi memberikan kesan perlindungan tulang berbanding dos tunggal dengan VCO atau TRF bagi menghalang kehilangan tulang pada model tikus osteoporotik.

Kata kunci: Osteoporosis, minyak kelapa dara, pecahan kaya tokotrienol, kekuatan biomekanikal, kelenturan tiga titik

(c) 2020 Penerbit UTM Press. All rights reserved

\subsection{INTRODUCTION}

Osteoporosis can be defined as progressive systemic disease characterized by low bone mass and loss of bone tissue as well as its microarchitecture with a consequent increased risk of fracture [1]. Osteoporosis causes more than 8.9 million fractures annually in the world [2]. It is estimated that by 2040 the number of osteoporotic patients above 50 -yearold will double worldwide from that of 2010 figures of 158 million [3, 4]. Around $30 \%$ of post-menopausal women in the world suffer from osteoporosis [5]. Meanwhile, the prevalence of osteoporosis in Malaysia was reported as $24.1 \%$ in 2005, predominantly affecting the hip [6]. The overall incidence of hip fractures was 90 per 100000 individuals [7]. Women have higher tendency to get osteoporosis compared to men with the ratio of 1.6:1 due to oestrogen deficiency which led to reduced protection against oxidative stress [8]. Many studies have shown that oxidative stress plays a role in the pathogenesis of osteoporosis $[9,10]$. Oxidative stress is caused by imbalance between the free radicals production (pro-oxidants) and reduced antioxidants level in the body [11]. Excessive pro-oxidants lead to abnormally higher concentrations of reactive oxygen species (ROS) [12], which enhance osteoclasts activity and inhibits osteoblasts differentiation, thus inducing bone loss. This condition can be prevented by minimizing the oxidative stress level.

Bone remodeling is a dynamic process that repairs microfractures throughout the skeleton and replaces old bone with new bone to maintain its overall function. The process is equivalent, which involves bone resorption by osteoclasts followed by formation of new bone by osteoblasts. It is controlled by cytokines, the polypeptide molecules, derived from marrow mononuclear cells or from bone cells themselves, such as macrophage-colony stimulating factor (M-CSF), tumor necrosis factor-a (TNF-a), interleukin-6 (IL-6), receptor activator of nuclear factor kappa B ligand (RANKL) and osteoprotegerin (OPG). The binding of M-CSF and RANKL to their respective surface receptors on osteoclast precursors enables them to differentiate into mature multinucleated osteoclast cells. This process is regulated by OPG, which competes with RANKL to inhibit osteoclast formation [13, 14]. However, the important action of oestrogen is to increase OPG secretion [15] and decrease M-CSF and RANKL [16]. In postmenopausal osteoporosis, oestrogen deficiency impairs the normal cycle by increasing osteoclastic resorption activity without a corresponding increase in osteoblastic activity, rendering it susceptible to bone loss and fracture. This mechanisms include RANKL upregulation, which leads to increased osteoclast activation, reduced OPG production by osteoblasts, increased expression of bone-resorbing cytokines, such as M-CSF, (TNF-a), (IL-6), and a direct effect on osteoclasts by increasing the differentiation of osteoclast precursors into mature osteoclasts [17].

Nowadays, there are many types of treatments to prevent postmenopausal osteoporosis such as sclerostin inhibitors [18], calcitonin [19], bisphosphonates [20] and selective oestrogen receptor modulators (SERMs) [21]. Nevertheless, the most important treatment is oestrogen replacement therapy (ERT), the gold standard treatment for postmenopausal osteoporosis [22, 23]. ERT is first choice for osteoporosis prevention in women less than 10 years of menopause while bisphosphonates are recommended for osteoporosis in older women more than 60 years. Then, SERMs are an alternative for women who cannot take both drugs [20]. However, postmenopausal women who had undergone ERT were found to have increased bone strength at both lumbar spine and proximal femur [24]. Unfortunately, prolonged use of this treatment causes long term adverse effects such as thromboembolic events, vaginal bleeding, endometrial and breast cancers $[25,26]$. Thus, findings linking ERT to various types of diseases have led to the researchers looking for alternative therapies in preventing of osteoporosis from natural remedies that have minimal side effects.

Antioxidants are known to reduce the harmful effects of oxidative stress on the cells. It can be formed either synthetically or naturally. Virgin coconut oil ( $\mathrm{VCO}$ ) is one of the natural antioxidantrich diets that can prevent bone loss caused by osteoporosis [27]. This fresh, mature, coconut kernel derived-oil is rapidly gaining popularity throughout the world. Unlike the ordinary coconut oil, VCO is different as it does not undergo heat and refining 
process. This preserves the important biologically active and antioxidants-rich components in the oil such as tocopherols, polyphenols, sterols and squalene [28]. Previous study by Zil et al. (2015) reported that single therapy of VCO given to the ovariectomised rats resulted in improved bone structure and prevented bone loss due to its high polyphenols components which exert antioxidant property [29].

Furthermore, the other antioxidant-rich diet is palm oil tocotrienol-rich fraction (TRF) which has a major source of the lipid-soluble compounds. Tocotrienols have three carbon double bonds $(\mathrm{C}=\mathrm{C})$ and an unsaturated isoprenoid side chains $(-\mathrm{CH} 3)$ that making it very unstable. This condition makes the tocotrienols have some physical antioxidant efficiency due to an ability to donate a hydrogen atom from the hydroxyl group on the chromanol ring to the free radical and ROS. Previous study showed that the configuration of unsaturated side chain allowed tocotrienol penetrates a layer of saturated fat quickly such as the brain and liver [30]. The result showed that there are two antioxidative functional groups namely the chromanol ring and the polyunsaturated phytol side chain, which makes tocotrienols a better antioxidant than tocopherols [31]. In addition, the number of electrons in the ROS does not correspond to a stable configuration, which induced oxidative stress and leading to cell damage that can culminate in cell death [32]. According to Musalmah et al. (2009), TRF was able to prevent the DNA damage, apoptosis and cell death [33]. Apart from that, bone calcium content in growing rats could also be improved [34]. A previous study also demonstrated that TRF supplementation in ovariectomised rats, could improve bone biomechanical strength when tested biomechanically [35]. Many studies were conducted by focusing on the bone strength and fracture risk in osteoporotic-rat model treated with single dose of VCO or TRF only [36, 37]. Thus, treatment of the ovariectomised rats with VCO and TRF only seem to reverse the effects of oestrogen deficiency on the bone structure. To the best of knowledge, there is no report to determine the effects of combination therapy of VCO and TRF on the bone biomechanical properties and its resistance to fracture.

The most common, simple, affordable and widely recognized method for bone strength parameters was the three-point bending test, in which the bones were examined as structures [38]. The current study was designed to determine the effects of two forms of well-known antioxidants, VCO and TRF, individually and in combination, on bone biomechanical properties (load, displacement, stiffness, stress, strain and Young modulus) of the ovariectomised rat fed with high cholesterol diet and repeatedly-heated palm oil. This would determine whether they are beneficial as alternative treatment from natural resources to prevent postmenopausal osteoporosis in future.

\subsection{METHODOLOGY}

\subsection{Animal and Treatment}

The research project was conducted from May 2014 to August 2016 in Universiti Kebangsaan Malaysia Medical Centre (UKMMC), Cheras, Kuala Lumpur, Malaysia. Thirty-six female Sprague-Dawley rats weighing between 250-300g were obtained from the Laboratory Animals Resource Unit, Faculty of Medicine, UKMMC. The rats were randomized into six groups where each group consists of six rats. The Sham-operated group (SHAM) was fed on rat chow diet and acted as sham-control. The ovariectomised (OVX) control group was given $15 \%$ of five times heated palm oil (5HPO) mixed with $2 \%$ cholesterol. The ovariectomised-treated groups were given 64.5 $\mu \mathrm{g} / \mathrm{kg}$ of Premarin $(\mathrm{OVX}+\mathrm{P}), 1.43 \mathrm{ml} / \mathrm{kg}$ of virgin coconut oil $(\mathrm{OVX}+\mathrm{V}), 30 \mathrm{mg} / \mathrm{kg}$ of TRF $(\mathrm{OVX}+\mathrm{T})$ and combination of $1.43 \mathrm{ml} / \mathrm{kg}$ of $\mathrm{VCO}$ and $30 \mathrm{mg} / \mathrm{kg}$ of TRF (OVX+VT). Animals from each of these groups were sacrificed 24 weeks later and the right femora were taken for analysis. The study was performed with approval from Research and Ethical Committee, Faculty of Medicine, UKMMC (Approval No. UKMAEC: FP/ANAT/2014/FAIZAH/16-JULY/599-JULY-2014-AUG2015-NAR-CAT2).

\subsection{Specimen Collection}

Following twenty-four weeks of treatment, the rats were anaesthetized with diethyl ether and sacrificed humanely by cervical dislocation. The right femora were dissected out and cleansed of all soft tissues using small scissors, tweezers and cotton gauze. Each right femur was always wrapped with gauze soaked in Phosphate Buffered Solution (PBS) and rewrapped with aluminum foil to keep moist. All the samples were stored in $-80^{\circ} \mathrm{C}$ freezer until use. On the day of testing, the right femora have been allowed to thaw at room temperature for 2 hours prior to additional sample preparation.

\subsection{Bone Biomechanical Test}

In this study, biomechanical properties of the right femoral bones were tested using three-point bending test method. The test was conducted using the Universal Testing machine (Model ShimadzU, AG-X $500 \mathrm{~N}$ ) (Figure 1) controlled by proprietary software (Trapezium X Version 1.00, Shimadzu). The total length and width of the midshaft were measured using a digital caliper. Each femur was placed in a threepoint bending configuration, which has two lower support points, one at each end with $10 \mathrm{~mm}$ apart, for supporting the bone (Figure 2). The points are perpendicular to the horizontal axis.

For femora testing, the anterior surface was faced downward and the posterior aspect of the femoral condyles faced upward. The loading point applied the force at the right femora mid-diaphysis. The force 
was applied at the rate of $10 \mathrm{~mm} / \mathrm{sec}$ which caused the anterior surface to be in compression and the posterior surface in tension until it fractured. At the beginning, the femur was in undeformed state (zero displacement) and the loading point makes a contact with the femur with a small preload $(<1 N)$ just enough to keep the bone in place. Then, the loading point was moved downward progressively with increasing applied load (or force, F) and displacement (d) until the femur broke. The load, displacement, stress and strain values were recorded during the test and were stored in the data file.

From the data, the whole bone geometry parameters and biomechanical properties were determined. The data from load-displacement and stress-strain were generated for analysis of stiffness and Young modulus, respectively. A graph of stress against strain was plotted. The slope value of the stress-strain curve represented the modulus of elasticity or Young modulus of the right femora. The parameters of the biomechanical strength were divided into the extrinsic parameters (load, displacement and stiffness) and the intrinsic parameters (stress, strain and Young modulus). The extrinsic and intrinsic parameters measured the properties of the whole right femora and the component of the right femora, respectively.

\subsection{Statistical Analysis}

The data analysis was performed using the Statistical Package for Social Sciences software (SPSS 25; Chicago, IL, USA). Firstly, the data was tested for normality using the Kolmogorov-Smirnov test ( $\mathrm{n}=$ <100). The results showed that the data were normally distributed. For normally distributed data, the statistical tests used were the analysis of variance (ANOVA), followed by Tukey's HSD test. All the results were expressed as mean \pm standard error of the mean (SEM).

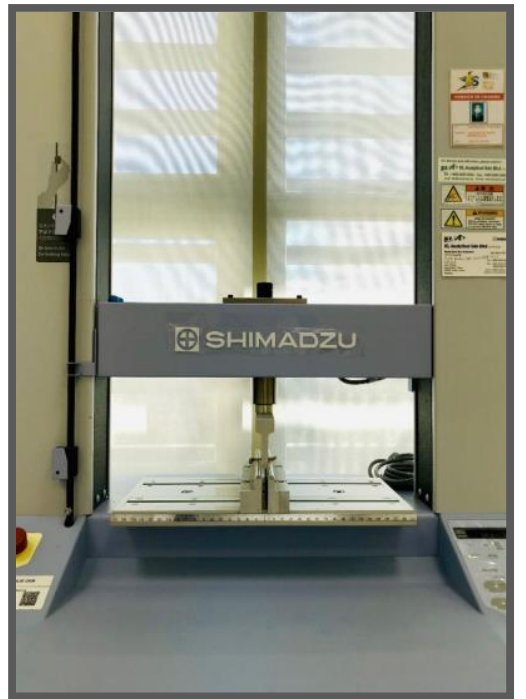

Figure 1 Universal Testing machine (Model Shimadzu, AG-X $500 \mathrm{~N})$

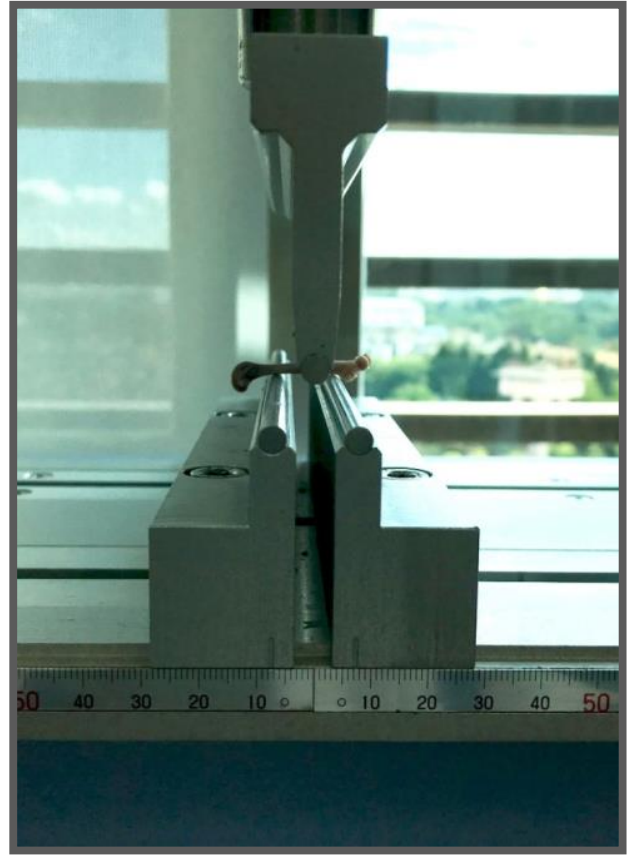

Figure 2 Load applied to the mid-diaphysis of right femur

\subsection{RESULTS AND DISCUSSION}

\subsection{Maximum Load}

There was no significant difference in maximum load value between the SHAM and OVX groups. The $O V X+P$ group showed slightly higher value of maximum load than the SHAM group. Otherwise, all treated groups of $\mathrm{OVX}+\mathrm{V}, \quad \mathrm{OVX}+\mathrm{T}$ and $\mathrm{OVX}+\mathrm{VT}$ showed no significant difference compared to the OVX group (Figure 3).

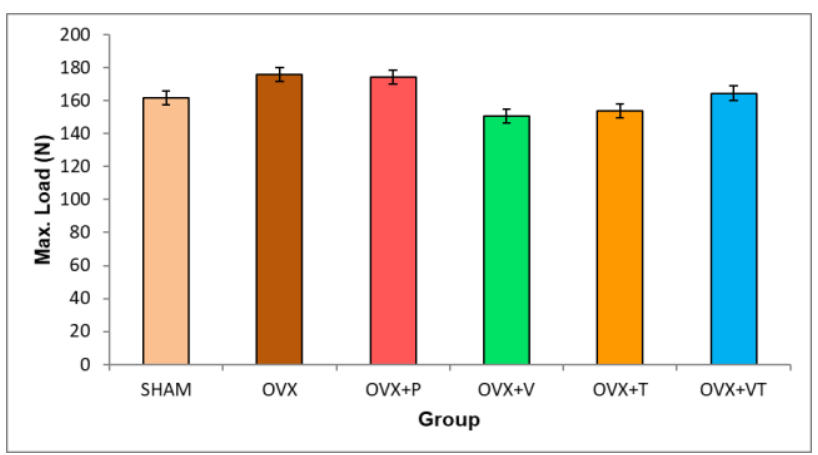

Figure 3 Maximum load value for all groups. Data presented as mean \pm SEM. SHAM: Sham-operated, OVX: ovariectomised control, OVX+P: ovariectomised and given Premarin $(64.5 \mu \mathrm{g} / \mathrm{kg}), O V X+V$ : ovariectomised and given VCO (1.43 ml/kg), OVX+T: ovariectomised and given TRF (30 $\mathrm{mg} / \mathrm{kg}$ ), OVX+VT: ovariectomised and given combined VCO-TRF supplementation 


\subsection{Maximum Displacement}

The OVX group showed significantly lower displacement value than the SHAM group. Displacement values for all treated groups were not reduced and similar to the SHAM group (Figure 4).

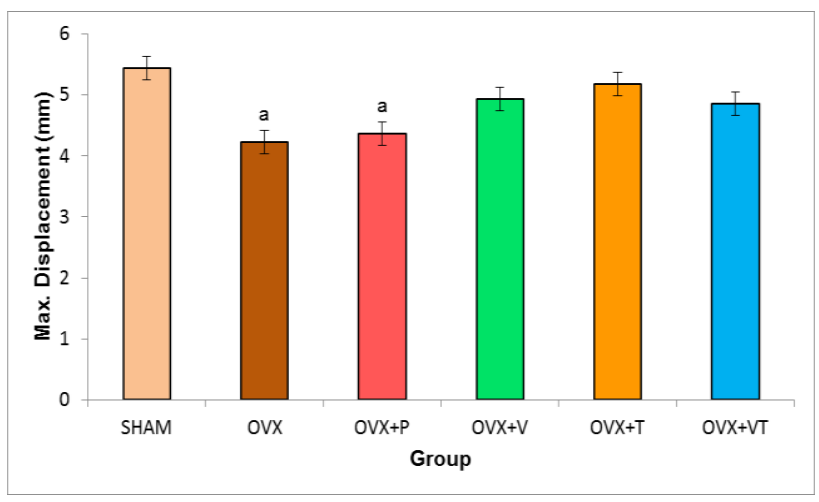

Figure 4 Maximum displacement value for all groups. Data presented as mean \pm SEM. SHAM: Sham-operated, OVX: ovariectomised control, OVX+P: ovariectomised and given Premarin $(64.5 \mu \mathrm{g} / \mathrm{kg}), O V X+V$ : ovariectomised and given VCO (1.43 ml $/ \mathrm{kg}), O V X+T$ : ovariectomised and given TRF (30 $\mathrm{mg} / \mathrm{kg}), \quad O V X+V T$ : ovariectomised and given combined VCO-TRF supplementation. $a^{*} p<0.05$ compared to the SHAM group

\subsection{Stiffness}

The data showed the stiffness value of the OVX group is significantly higher than the SHAM group. The $O V X+T$ group showed significantly lower value than the OVX group. Otherwise, there was no significant difference reported between the $\mathrm{OVX}+\mathrm{V}$ and OVX+VT groups compared to the SHAM and OVX groups (Figure 5).

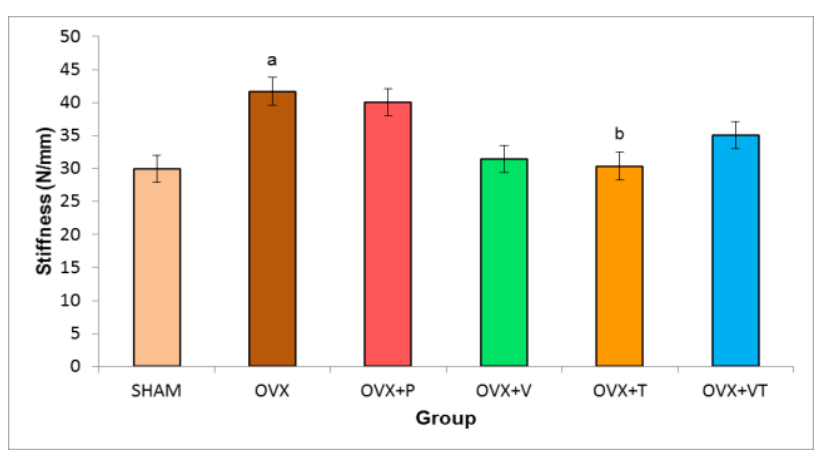

Figure 5 Maximum stiffness value for all groups. Data presented as mean \pm SEM. SHAM: Sham-operated, OVX: ovariectomised control, $O V X+P$ : ovariectomised and given Premarin $(64.5 \mu \mathrm{g} / \mathrm{kg}), O V X+V$ : ovariectomised and given VCO (1.43 ml/kg), OVX+T: ovariectomised and given TRF (30 $\mathrm{mg} / \mathrm{kg}), \quad O V X+V T$ : ovariectomised and given combined VCO-TRF supplementation. $a^{*} p<0.05$ compared to the SHAM group, b* $p<0.05$ compared to the OVX group

\subsection{Maximum Stress}

The $O V X+V$ and $O V X+T$ groups showed significantly lower stress value than the SHAM group. All the treated groups showed no significant difference compared to the OVX group. The combined VT group was not significantly different compared to OVX group (Figure 6).

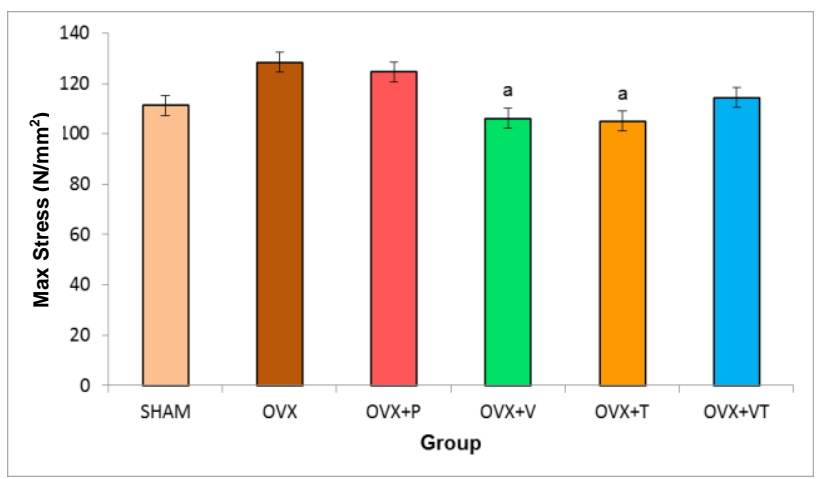

Figure 6 Maximum stress value for all groups. Data presented as mean + SEM. SHAM: Sham-operated, OVX: ovariectomised control, OVX+P: ovariectomised and given Premarin $(64.5 \mu \mathrm{g} / \mathrm{kg}), O V X+V$ : ovariectomised and given VCO (1.43 ml/kg), OVX+T: ovariectomised and given TRF (30 $\mathrm{mg} / \mathrm{kg}), \quad O V X+V T$ : ovariectomised and given combined VCO-TRF supplementation. $a^{*} p<0.05$ compared to the OVX group

\subsection{Maximum Strain}

The OVX and OVX+P groups showed significantly lower strain values than the SHAM group. There was a significantly higher strain value in the $\mathrm{OVX}+\mathrm{T}$ group compared to the OVX group (Figure 7).

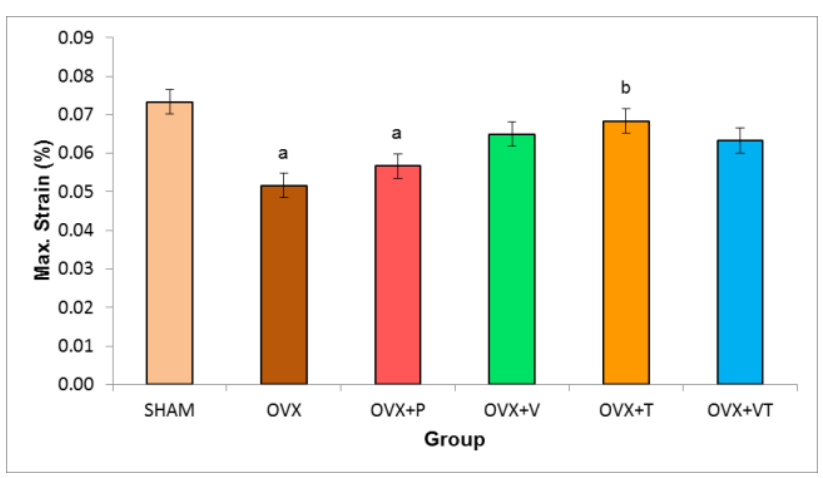

Figure 7 Maximum strain value for all groups. Data presented as mean \pm SEM. SHAM: Sham-operated, OVX: ovariectomised control, OVX+P: ovariectomised and given Premarin $(64.5 \mu \mathrm{g} / \mathrm{kg}), O V X+V$ : ovariectomised and given VCO (1.43 ml/kg), OVX+T: ovariectomised and given TRF (30 $\mathrm{mg} / \mathrm{kg}), \quad O V X+V T$ : ovariectomised and given combined VCO-TRF supplementation. $a^{*} p<0.05$ compared to the SHAM group, $b^{*} p<0.05$ compared to the OVX group 


\subsection{Young Modulus}

The OVX and OVX+P groups showed a significantly higher Young modulus value than the SHAM group. A significantly higher Young modulus value in the OVX+VT group could be seen compared to the $O V X+V$ and $O V X+T$ groups (Figure 8).

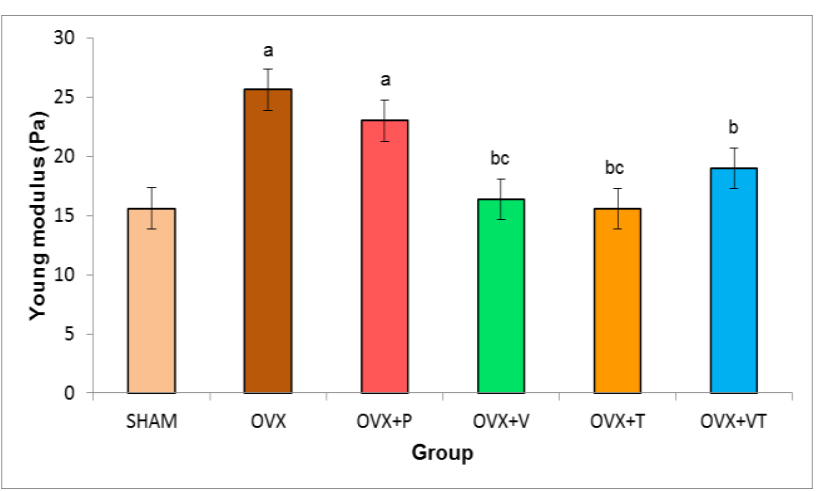

Figure 8 Young modulus value for all groups. Data presented as mean \pm SEM. SHAM: Sham-operated, OVX: ovariectomised control, OVX+P: ovariectomised and given Premarin $(64.5 \mu \mathrm{g} / \mathrm{kg}), O V X+V$ : ovariectomised and given VCO $(1.43 \mathrm{ml} / \mathrm{kg}), O V X+T$ : ovariectomised and given TRF $(30 \mathrm{mg} / \mathrm{kg}), O V X+V T$ : ovariectomised and given combined VCO-TRF supplementation. $a^{*} p<0.05$ compared to the SHAM group, b* $p<0.05$ compared to the OVX group, $c^{*}$ $\mathrm{p}<0.05$ compared to the OVX+P group

Bone tissue is a complex tissue that composed of the osteoblasts and osteoclasts. Osteoblasts are important in new bone formation whereas osteoclasts, are the primary bone cells that responsible for bone resorption activity. The ongoing balance between osteoblasts and osteoclasts are responsible for the constant, but subtle, remodeling of bone, which is crucial in maintaining bone strength, thus preventing osteoporosis [39]. Their activities may be influenced by various factors such as oestrogen level secreted by the ovaries as well as the free radicals. Previous study has reported that oestrogen plays an important role in the regulation of bone turnover and its deficiency is associated with increased bone resorption due to increased osteoclasts and reduced osteoblasts activities [40]. Another study revealed that oestrogen deficiency led to decrease defense against oxidative stress which has the inhibitory effect on bone formation [41]. Based on this condition, antioxidant supplementation was investigated as alternative treatment for osteoporosis.

Hormone replacement therapy (HRT) has long been used as a treatment of osteoporosis but this has been proven to cause some undesirable adverse effects. Therefore, VCO and TRF-rich in antioxidant were selected as supplements to the ovariectomised rats in our study. Two from the six groups of SpragueDawley rats were supplemented with a single dose of VCO $(1.43 \mathrm{ml} / \mathrm{kg})$ and TRF $(30 \mathrm{mg} / \mathrm{kg})$ only. Another group was supplemented with extra antioxidant by combining VCO and TRF. Previous studies have shown that single dose supplementation of VCO or TRF contributed to anti-osteoporosis effects in ovariectomised rat models [42, 43]. Following these positive results, the present study was done to investigate the combination effects of both VCO and TRF in their resistance level to bone fracture. In accordance with this, biomechanical test using three-point bending were done to evaluate bone strength and its mechanical properties.

The current study showed significant improvement in both extrinsic and intrinsic parameters. For extrinsic parameters, displacement parameter can be defined as length of deformation that the bone can sustain before it breaks. The OVX group showed deterioration in bone ductility compared to the sham-operated group. This result matched with previous study which reported that decreased oestrogen level via ovariectomy led to decreased in cortical bone strength [44]. There was an increasing trend of displacement value between the treated groups $(\mathrm{OVX}+\mathrm{V}, \mathrm{OVX}+\mathrm{T}$ and $\mathrm{OVX}+\mathrm{VT})$ compared to the OVX group. This showed that ovariectomised rats given these supplementations produced more ductile bones, hence they were harder to break. Nevertheless, other extrinsic parameters such as load and stiffness showed no statistical difference between all groups.

Strain is an intrinsic parameter used to determine the deformation of the femoral bone when loaded with a force. The $O V X+V, O V X+T$ and $O V X+V T$ groups demonstrated higher values than the OVX and OVX+P groups. According to Malik et al. (2019), treatment with VCO and TRF, individually and combination, increased bone volume of ovariectomised rat based on the structural histomorphometry parameter [45]. For this parameter, $\mathrm{OVX}+\mathrm{T}$ group showed more superior strain value than both $\mathrm{OVX}+\mathrm{V}$ and $\mathrm{OVX}+\mathrm{VT}$ groups.

Young modulus and maximum stress are also intrinsic parameter. Young modulus is a modulus of elasticity which is represented by the slope from the stress-strain curve. This parameter is greatly influenced by the amount of collagen and calcification process in the bone. Maximum stress parameter measured the load per unit area received by the femur before it fractured. There was significant increased value of OVX group compared to SHAM and treated groups. This result was contrary with the study done by Fathilah et al. (2012), which demonstrated that Young modulus and maximum stress values of ovariectomised group were significantly lower than the treated groups [46]. This was probably caused by the longer duration of treatment of 24 weeks compared to 8 weeks for the previous study. The Young modulus and maximum stress values of OVX+VT group was better than $O V X+V$ and $O V X+T$ groups.

Several possible mechanisms are associated with the ability of virgin coconut oil (VCO) and palm oil tocotrienol-rich fraction (TRF) to reduce fracture risk 
during oestrogen deficiency state. VCO is known to have higher polyphenols, tocopherols and vitamins contents while palm oil contains higher betacarotene, tocotrienol and other antioxidants as well. Recent studies showed that TRF, extracted from annatto was the most effective and significantly increased lysyl oxidase (LOX) expression, which is required for the formation of bone collagen crosslinks. Inactivation of the LOX gene in osteoblasts has been reported to cause loss of cross-links and an increased risk of fractures [47]. Therefore, VCO and TRF have potential in maintaining the bone strength by reducing and increasing the osteoclastic and osteoblastic activities, respectively.

Based on the strain parameter, supplementation with TRF offered the best protection against osteoporosis as shown by the significantly higher value than ovariectomised control group. However, based on the other biomechanical parameters, especially Young modulus, combined supplementation of VCO and TRF (OVX+VT group), have offered better bone protective effects than single supplementation with VCO or TRF.

\subsection{CONCLUSION}

The more superior osteoprotective effects of VCO-TRF supplementation indicated their worthiness as alternative therapy for preventing bone loss in the osteoporotic rat model. Further studies are required to determine the anti-osteoporotic mechanism of action for these supplementations in treating postmenopausal osteoporosis.

\section{Limitations}

There was limitation in this study due to lack of scholarly paper addressing the combination therapy of the natural products. The previous studies have focused more on single dose of VCO or TRF only. In addition, there are also no study that focused on 24 weeks long-term effect of the treatment, although the previous studies have done in the short-term between 6 and 10 weeks. Thus, we believed that valuable information regarding the protective effects of VCO-TRF combination in osteoporosis will be helpful in treating the bone damage of postmenopausal women caused by osteoporosis.

\section{Acknowledgement}

The authors expressed their gratitude to Mr. Mohd Mustazil Mohd Noor and Mrs. Juliana Abdul Hamid from the Department of Pharmacology, Faculty of Medicine, Universiti Kebangsaan Malaysia Medical Centre (UKMMC), Cheras, Kuala Lumpur, for their technical support.

\section{References}

[1] Lelovas, P. P., T. T. Xanthos, S. E. Thoma, G. P. Lyritis \& I. A. Dontas. 2008. The Laboratory Rat as an Animal Model for Osteoporosis Research. Comparative Medicine. 58(5): 424-430. PubMed PMID: 19004367; PubMed Central PMCID: PMC2707131.

[2] Johnell, $O$ and J. A. Kanis. 2006. An Estimate of the Worldwide Prevalence and Disability Associated with Osteoporotic Fractures. Osteoporos Int. 17: 1726.

DOI: 10.1007/s00198-006-0172-4.

[3] Kates, S. L., O. S. Kates and D. A. Mendelson. 2007. Advances in the Medical Management of Osteoporosis. Injury. 38: S17-23.

DOI: 10.1016/j.injury.2007.08.007.

[4] IOF Compendium of Osteoporosi. 1st ed. 2017. Available from: www. iofbonehealth.org.

[5] Kanis, J. A. 1994. Assessment of Fracture Risk and its Application to Screening for Postmenopausal Osteoporosis. Report of a WHO Study Group. Osteoporos Int. 4(6): 368-81. DOI: $10.1007 /$ bf01622200.

[6] Lim, P. S., F. B. Ong, N. Adeeb, S. S. Seri, Noor-Aini et al. 2005. Bone Health in Urban Midlife Malaysian Women: Risk Factors and Prevention. Osteoporos Int. 16: 2069-79. DOI: 10.1007/s00198-005-2003-4.

[7] Lee, J. K and A. S. M. Khir. 2007. The Incidence of Hip Fracture in Malaysians above 50 Years of Age: Variation in Different Ethnic Groups. APLAR Journal of Rheumatology. 10: 300-305 DOl: https://doi.org/10.111 1/j.1479-8077.2007.00314.x.

[8] Shuid, A. N., L. L. Ping, N. Muhammad, N. Mohamed \& I. N. Soelaiman. 2011. The Effects of Labisia pumila var. alata on Bone Markers and Bone Calcium in a Rat Model of Post-menopausal Osteoporosis. Journal of Ethnopharmacology. 133(2): 538-542. DOI: https://doi.org/10.1016/j.jep.2010.10.033.

[9] Madenci, E., \$̧. Güçbey, I. Koca, E. Ibas and H. Çiçek. 2009. Serum Total Oxidative and Antioxidative Status in Patients with Postmenopausal Osteoporosis. Clinical Biochemistry. 42: 4-5.

DOI: https://doi.org/10.1016/j.clinbiochem.2008.09.083.

[10] Deveci, H., G. Nur, H. Cicek \& M. Karapehlivan. 2017. Evaluation of Oxidative Stress Factors in Patients with Osteoporosis. Medicine Science. 6: 479-82. DOI: 10.5455/medscience.2017.06.8597.

[11] Rao, L., N. Kang and A. Rao. 2012. Polyphenol Antioxidants and Bone Health: A Review. PhytochemicalsA Global Perspective of Their Role in Nutrition and Health. IntechOpen. 467-80.

DOI: $10.5772 / 39287$.

[12] Rahal, A., A. Kumar, V. Singh, B. Yadav, R. Tiwari, S. Chakraborty \& K. Dhama. 2014. Oxidative Stress, Prooxidants, and Antioxidants: The Interplay. BioMed Research International. 761264. DOI: $10.1155 / 2014 / 761264$.

[13] Martin, T. J. \& N. A. Sims. 2005. Osteoclast-derived Activity in the Coupling of Bone Formation to Resorption. Trends Mol Med. 11 (2): 76-81. DOI: 10.1016/j.molmed.2004.12.004.

[14] Sims, N. A. \& J. H. Gooi. 2008. Bone Remodeling: Multiple Cellular Interactions Required for Coupling of Bone Formation and Resorption. Semin. Cell Dev. Biol. 19(5): 444-51.

DOI: 10.1016/j.semcdb.2008.07.016.

[15] Hofbaver, L. C. et al. 2000. The Roles of Osteoprotegerin and Osteoprotegerin Ligand in the Paracrine Regulation of Bone Resorption. J. Bone Miner. Res. 15: 2-12. DOI: 10.1359/jbmr.2000.15.1.2.

[16] Shevde, N. K., A. C. Bendixen, K. M. Dienger \& J. W. Pike. 2000. Estrogens Suppress RANK Ligandinduced Osteoclast Differentiation via a Stromal Cell Independent Mechanism Involving C-Jun Repression. Proc. Natl. Acad. Sci. USA. 97: 7829-7834. 
DOI: $10.1073 /$ pnas. 130200197.

[17] Clarke, B. L. \& S. Khosla. 2010. Physiology of Bone Loss. Radiol. Radiol Clin North Am. 48(3): 483-95. DOI: 10.1016/j.rcl.2010.02.014.

[18] Li, X., M. S. Ominsky, K. S. Warmington et al. 2009. Sclerostin Antibody Treatment Increases Bone Formation, Bone Mass, and Bone Strength in a Rat Model of Postmenopausal Osteoporosis. J Bone Miner Res. 24: 578. DOI: https://doi.org/10.1359/jbmr.081206.

[19] Binkley, N., M. Bolognese, A. Sidorowicz-Bialynicka, T. Vally, R. Trout, C. Miller, C. E. Buben, J. P. Gilligan and D. S. Krause. 2012. Oral Calcitonin in Postmenopausal Osteoporosis (ORACAL) Investigators. I Bone Miner Res. 27(8): 1821-9.

DOl: https://doi.org/10.1002/jbmr.1602.

[20] Tella, S. H. \& J. C. Gallagher. 2014. Prevention and Treatment of Postmenopausal Osteoporosis. The Journal of Steroid Biochemistry and Molecular Biology. 142: 155170.

DOI: https://doi.org/10.1016/j.jsbmb.2013.09.008.

[21] An K. C. 2016. Selective Estrogen Receptor Modulators. Asian Spine Journal. 10(4): 787-791.

DOI: https://doi.org/10.4184/asj.2016.10.4.787.

[22] Anderson, G. L., M. Limacher, A. R. Assaf, T. Bassford, S. A. Beresford, et al. 2004. Effects of Conjugation Equine Estrogen in Postmenopausal Women with Hysterectomy: the Women's Health Initiative Randomized Controlled Trial. JAMA. 291(14): 1701-1712. DOI: 10.1001/jama.291.14.1701.

[23] Manson, J. E., R. T. Chlebowski, M. L. Stefanick, A. K. Aragaki, J. E. Rossouw, et al. 2013. Menopausal Hormone Therapy and Health Outcomes During the Intervention and Extended Post-stopping Phases of the Women's Health Initiative Randomized Trials. JAMA. 310(13): 13531368.

DOI: 10.1001/jama.2013.278040.

[24] Mohd Effendy, N., S. Abdullah, M. F. M. Yunoh \& A. N. Shuid. 2015. Time and Dose-dependent Effects of Labisia pumila on the Bone Strength of Postmenopausal Osteoporosis Rat Model. BMC Complementary and Alternative Medicine. 15(1): 58. DOI: https://doi.org/10.1186/s12906-015-0567-x.

[25] Pradhan, A. D., J. E. Manson, J. E. Rossouw, D. S. Siscovick, C. P. Mouton, N. Rifai, R. B. Wallace, R. D. Jackson, M. B. Pettinger \& P. M. Ridker. 2002. Inflammatory Biomarkers, Hormone Replacement Therapy, and Incident Coronary Heart Disease: Prospective analysis from the Women's Health Initiative Observational Study. JAMA. 288: 980-987. DOI: $10.1001 /$ jama.288.8.980.

[26] Wei, M., Z. Yang, P. Li, Y. Zhang and W. C. Sse. 2007. Antiosteoporosis Activity of Naringin in the Retinoic Acidinduced Osteoporosis Model. Am J Chin Med. 35: 663-667. DOI: $10.1142 / S 0192415 \times 07005156$.

[27] Abujazia, M. A., N. Muhammad, A. N. Shuid \& I. N. Soelaiman. 2012. The Effects of Virgin Coconut Oil on Bone Oxidative Status in Ovariectomised Rat. EvidenceBased Complementary and Alternative Medicine: eCAM. 525079.

DOI: $10.1155 / 2012 / 525079$.

[28] Marina, A. M., Y.B. Che Man and I. Amin. 2009. Virgin Coconut Oil: Emerging Functional Food Oil. Trends in Food Science \& Technology. 20(10): 481-487. DOI: https://doi.org/10.1016/j.tifs.2009.06.003

[29] Hayatullina, Z., N. Muhammad, N. Mohamed and I. N. Soelaiman. 2012. Virgin Coconut Oil Supplementation Prevents Bone Loss in Osteoporosis Rat Model. Evidencebased Complementary and Alternative Medicine. 237236. DOI: $10.1155 / 2012 / 237236$.

[30] YU, F. L., A. Gapor \& W. Bender. 2005. Evidence for the Preventive Effect of the Polyunsaturated Phytol Side Chain in Tocotrienols on $17 \beta$-estradiol Epoxidation. Cancer Detect Prev. 29: 383-388.

DOI: https://doi.org/10.1016/j.cdp.2005.03.003.
[31] Packer, L., S. U. Weber \& G. Rimbach. 2001. Molecular Aspects of A-Tocotrienol Antioxidant Action and Cell Signalling. J Nutr. 131: 369-373. DOI: 10.1093/jn/131.2.369S.

[32] Poljsak, B., D. Šuput \& I. Milisav. 2013. Achieving the Balance between ROS and Antioxidants: When to Use the Synthetic Antioxidants. Oxidative Medicine and Cellular Longevity. 2013: 956792.

DOI: https://doi.org/10.1155/2013/956792.

[33] Musalmah et al. 2009. Induction of DNA Damage and Cell Death by Beta Amyloid Peptide and Its Modification by Tocotrienol Rich Fraction (TRF). Med \& Health. 4(1): 8-15. DOI: http://journalarticle.ukm.my/1910/.

[34] Hamsi, M., F. Othman, S. Das, Y. Kamisah, Z. Thent and H. Qodriyah et al. 2015. Effect of Consumption of Fresh and Heated Virgin Coconut Oil on the Blood Pressure and Inflammatory Biomarkers: An Experimental Study in Sprague Dawley Rats. Alexandria Journal of Medicine. 51 (1): 53-63.

DOl: https://doi.org/10.1016/j.ajme.2014.02.002.

[35] Nazrun, A. S., A. Khairunnur, M. Norliza, M. Norazlina and S. Ima Nirwana. 2008. Effects of Palm Tocotrienols on Oxidative Stress and Bone Strength in Ovariectomised Rats. Medicine \& Health. 3(2): 247-255.

[36] Muhammad, N., D. A. Luke, A. N. Shuid, N. Mohamed \& I. N. Soelaiman. 2013. Tocotrienol Supplementation in Postmenopausal Osteoporosis: Evidence from a Laboratory Study. Clinics (Sao Paulo, Brazil). 68(10): 13381343. DOI: 10.6061/clinics/2013(10)08.

[37] Elkomy, M. and F. Elsaid. 2015. Anti-osteoporotic Effect of Medical Herbs and Calcium Supplementation on Ovariectomised Rats. The Journal of Basic \& Applied Zoology. 72: 81-88.

DOl: https://doi.org/10.1016/j.jobaz.2015.04.007

[38] Jepsen, K. J., M. J. Silva, D. Vashishth, X. E. Guo \& M. C. van der Meulen. 2015. Establishing Biomechanical Mechanisms in Mouse Models: Practical Guidelines for Systematically Evaluating Phenotypic Changes in the Diaphyses of Long Bones. Journal of Bone and Mineral Research: The Official Journal of the American Society for Bone and Mineral Research. 30(6): 951-966. DOI: 10.1002/jbmr.2539.

[39] Suchacki, K. J. et al. 2017. Skeletal Energy Homeostasis: A Paradigm of Endocrine Discovery. J. Endocrino. 234: R67R79. DOI: 10.1530/JOE-17-0147.

[40] Jenneke, K. N., F. M. René, D. B. Astrid and G. B. Rommel. 2015. Bone Cell Mechanosensitivity, Estrogen Deficiency, and Osteoporosis. Journal of Biomechanics. 48(5): 855865.

DOI: https://doi.org/10.1016/j.jbiomech.2014.12.007.

[41] Manolagas, S. C. 2010. From Estrogen-centric to Aging and Oxidative Stress: A Revised Perspective of the Pathogenesis of Osteoporosis. Endocrine Reviews. 31 (3): 266-300. DOI: 10.1210/er.2009-0024.

[42] Abdul-Hamid, S., N. Muhammad and I. N. Mohamed. 2016. The Effects of Virgin Coconut Oil on Postmenopausal Osteoporotic Bone: Analyses on Osteoblastogenesis and Antioxidant Genes. Sains Malaysiana. 45(12): 1815-1822. DOI: https://www.scopus.com/inward/record.uri?eid=2 s2.0-85008221186.

[43] Ima-Nirwana, S., M. Wang and A. B. Roshayati et al. 2012. Palm Tocotrienol Supplementation Enhanced Bone Formation in Oestrogen-Deficient Rats. International Journal of Endocrinology. 532862: 7. DOI: $10.1155 / 2012 / 532862$.

[44] Camargos, G. V., P. Bhattacharya, G. H. van Lenthe, A. A. Del Bel Cury, I. Naert, J. Duyck and K. Vandamme. 2015 Mechanical Competence of Ovariectomy-induced Compromised Bone After Single or Combined Treatment with High-Frequency Loading and Bisphosphonates. Scientific Reports. 5: 10795.

DOI: 10.1038/srep 10795 
[45] Malik, M., Othman, F., Hussan, F., Shuid, A. N., \& Saad, Q. M. 2019. Combined Virgin Coconut Oil and TocotrienolRich Fraction Protects Against Bone Loss in Osteoporotic Rat Model. Veterinary World. 12(12): 2052-2060. DOI: https://doi.org/10.14202/vetworld.2019.2052-2060.

[46] Fathilah, S. N., S. Abdullah, N. Mohamed \& A. N. Shuid. 2012. Labisia pumila Prevents Complications of Osteoporosis by Increasing Bone Strength in a Rat Model of Postmenopausal Osteoporosis. Evidence-based Complementary and Alternative Medicine: Ecam. 948080. DOI: $10.1155 / 2012 / 948080$.

[47] Kohno, K, W. Yamada, A. Ishitsuka, M. Sekine, N. Virgona M. Ota \& T. Yano. 2020. Tocotrienol-rich Fraction from Annatto Ameliorates Expression of Lysyl Oxidase in Human Osteoblastic MG-63 Cells. Bioscience, Biotechnology, and Biochemistry. 84(3): 526-535.

DOI: 10.1080/09168451.2019.1693252. 